\title{
Corneal Asphericity and Optical Performance after Myopic Laser Refractive Surgery
}

\author{
Jeong-Mee Kim ${ }^{1}$, A-Young Lee ${ }^{1}$, and Koon-Ja Lee ${ }^{1,2, *}$ \\ ${ }^{1}$ Graduate School Dept. of Optometry, Eulji University, Daejeon 301-832, Korea \\ ${ }^{2}$ Dept. of Optometry, Eulji University, Sungnam 461-713, Korea \\ (Received April 23, 2013: Revised May 23, 2013: Accepted June 15, 2013)
}

\begin{abstract}
Purpose: To compare corneal asphericity, visual acuity (VA), and ocular and corneal higher-order aberrations (HOAs) between myopic refractive surgery and emmetropia groups. Methods: Twenty three subjects $(23.0 \pm 2.5$ years) who underwent myopic refractive surgery and twenty emmetropia (21.0 \pm 2.6 years) were enrolled. The subjects' criteria were best unaided monocular VA of 20/20 or better in both two groups. High and low contrast $\log$ MAR visual acuities were measured under photopic and mesopic conditions. Corneal and ocular HOAs were measured using Wavefront Analyzer (KR-1W, Topcon) for $4 \mathrm{~mm}$ and $6 \mathrm{~mm}$ pupils. Corneal asphericity was taken by topography in KR-1W. Results: There was no significant difference in VA between two groups under either photopic or mesopic conditions. In ocular aberrations, there were significant differences in total HOAs, fourthorder and spherical aberration (SA) for a $6 \mathrm{~mm}$ between two groups $(\mathrm{p}=0.045, \mathrm{p}<0.001$, and $\mathrm{p}<0.001$, respectively). In corneal aberrations, there was a significant difference in SA for $4 \mathrm{~mm}(\mathrm{p}=0.001)$ and $6 \mathrm{~mm}$ $(p<0.001)$ pupils between two groups and there were statistically significant differences in total HOAs $(p<0.001)$ and fourth-order aberrations $(\mathrm{p}<0.001)$ between two groups for a $6 \mathrm{~mm}$ pupil. There was a significant correlation in emmetropia between Q-value and SA in ocular aberrations for $4 \mathrm{~mm}$ and $6 \mathrm{~mm}$ pupils $(\mathrm{r}=0.442, \mathrm{p}=0.004$, and $\mathrm{r}=0.519, \mathrm{p}<0.001)$ and in corneal aberrations for $4 \mathrm{~mm}$ and $6 \mathrm{~mm}$ pupils $(\mathrm{r}=0.358, \mathrm{p}=0.023$, and $\mathrm{r}=0.646$, $\mathrm{p}<0.001)$. No significant correlations were found between Q-value and SA in refractive surgery group. Conclusions: VA in myopic refractive surgery is better than or similar to emmetropia. Nevertheless, the more increasing pupil size is, the more increasing aberrations are. Thus, it could have an influence on the quality of vision at night.
\end{abstract}

Key words: Higher-order aberrations, Spherical aberration, Corneal asphericity, Refractive surgery

\section{INTRODUCTION}

With the advances of wavefront technology and laser technology, refractive surgery is now used as a means for correcting monochromatic higher-order aberrations (HOAs) beyond spherical and astigmatic refractive errors in clinical practice. New technology of the aberrometer could allow us to measure HOAs, such as coma, trefoil, spherical aberration, and tetrafoil. The aberrometers have led to investigations of how HOAs affect visual performance and give us a better understanding of our visual systems. ${ }^{[1-3]}$ Ocular aberrations that combine various HOAs in optical systems produce defects in retina image quality. ${ }^{[4]}$ In a nor- mal, spherical aberration is one of the largest of the HOAs. ${ }^{[5]}$ Previous studies have shown that HOAs become significant factors in the quality of vision after correcting lower order aberrations. ${ }^{[6,7]}$ Correcting lower order aberrations by refractive surgery does not always provide for maintenance and enhancement of our vision. Furthermore, many factors including an irregular corneal shape or changed corneal shape can induce aberrations. The shape change in cornea after refractive surgery can have an impact on corneal asphericity and HOAs, especially in terms of spherical aberration and coma. ${ }^{[8,9]}$ In addition to this, the effect of HOAs on vision depends on pupil size. ${ }^{[10,11]}$

The purpose of this study was to compare not only the 
changes of high or low contrast visual acuity in both photopic and mesopic conditions but also ocular, corneal, and internal HOAs for $4 \mathrm{~mm}$ and $6 \mathrm{~mm}$ pupils between emmetropic eyes and eyes undergone laser in-situ keratomileusis (LASIK) or laser sub-epithelial keratectomy (LASEK) for myopia and to analyze the influence of corneal asphericity on spherical aberration in two groups.

\section{METHODS}

\section{Subjects}

Subjects were recruited from the Dept. of Optometry of Eulji University. There were 23 subjects who underwent conventional myopic LASIK or LASEK (except wavefront-guided refractive surgery) and 20 emmetropia subjects. The demographics and biometric data of the subjects are listed in Table 1. The subjects who met the criterion that was best unaided monocular VA of 20/20 (including no more than $0.50 \mathrm{D}$ of astigmatic refractive errors) or better in both two groups were selected for this study. None of the subjects had any ocular diseases other than refractive errors or refractive surgery.

\section{Visual acuity testing}

VA was measured by subjective manifest refractions under photopic and mesopic conditions with a natural pupil, using a high (100\%) and low (10\%)-contrast ETDRS acuity charts. VA score was recorded by $\log$ MAR units. There were five letters for each line in the ETDRS acuity charts and each letter was assigned a score of $0.02 \log$ units. The test was ended when subjects read twice incorrectly. The testing distance was $4 \mathrm{~m}$. The illumination at the eye plane

Table 1. Subjects' demographics and biometric data

\begin{tabular}{c|c|c}
\hline & Post-operative group & Emmetropia group \\
\hline Number of eyes & 46 & 40 \\
\hline Sex(M, F) & 9,14 & 10,10 \\
\hline Age (years) & $23.0 \pm 2.5$ & $21.0 \pm 2.6$ \\
\hline Flat K(D) & $37.76 \pm 3.65$ & $42.21 \pm 1.91$ \\
\hline Steep K(D) & $38.55 \pm 4.36$ & $43.24 \pm 1.75$ \\
\hline E-value & $0.00 \pm 0.00$ & $0.48 \pm 0.02$ \\
\hline Q-value & $0.48 \pm 0.04$ & $-0.25 \pm 0.01$ \\
\hline Pupil size (mm) & $6.00 \pm 0.49$ & $6.00 \pm 0.76$ \\
\hline
\end{tabular}

E, eccentricity; K, keratometry; Q-value, corneal asphericity for high contrast visual acuity (HCVA) and low contrast visual acuity (LCVA) under photopic and mesopic conditions was 340 lux and 20 lux, respectively (Digital Light Meter, TES-1330A, Taiwan).

\section{Wavefront aberration measurement}

Ocular wavefront aberrations were measured by Wavefront Analyzer (KR-1W, Topcon, Japan) with a Hartmannshack aberrometry. In this study, ocular, corneal and internal higher-order aberrations for $4 \mathrm{~mm}$ and $6 \mathrm{~mm}$ pupils were measured. The root mean square (RMS) of the third-order Zernike coefficients was used to represent third-order aberrations and the RMS of the fourth-order coefficient was used to represent fourth-order aberrations. Total HOAs were calculated as the RMS of the third-order and fourth-order coefficients. In order to maximize the influence of pupil size, ocular aberration measurement was performed in a dark room and taken on the unaided eye. All measurements were carried out monocularly with an undilated pupil. Pupil diameter was taken under a dark room with a natural pupil using KR-1W, where a pupillometry function is incorporated within the Wavefront Analyzer.

\section{Corneal topography measurement}

Corneal asphericity, eccentricity and $\operatorname{sim} \mathrm{K}$ were measured by KR-1W, where corneal topography function is incorporated within the Wavefront Analyzer. The corneal asphericity coefficient $Q$ describes the rate of variation in the curvature of the cornea from its center to the periphery. ${ }^{[12,13]}$

\section{Statistical analysis}

VA was compared between emmetropic and myopic refractive surgery groups by performing the independent $t-$ test. For root mean square (RMS) values of HOAs, comparisons between the two groups were also analyzed by the independent t-test. The results were expressed as mean $\pm \mathrm{SD}$. Pearson correlation test was analyzed for correlation between spherical aberration and corneal asphericity (Q-value) in emmetropia or conventional refractive surgery eyes. Origin 8.0 program (OriginLab Co., Northampton, USA) was used for statistical analysis throughout this study. For statistical significance, $\mathrm{p}$ value of $<0.05$ was used. 


\section{RESULTS}

Twenty-three subjects who underwent conventional myopic LASIK or LASEK and 20 emmetropia subjects were participated in this study. The mean age of the 23 laser refractive surgical subjects was $23.0 \pm 2.5$ years (range 20 to 27 ), and the period after refractive surgery was $16.0 \pm$ 12.1 months. The mean age of emmetropia subjects was $21.0 \pm 2.6$ years (range 19 to 24 ).

\section{Visual acuity}

Visual acuity under photopic and mesopic lighting conditions is summarized in Table 2.

In emmetropia group, HCVA and LCVA under photopic conditions were $0.003 \pm 0.005$ and $0.172 \pm 0.008$, respectively. In myopic refractive surgery group, Log MAR VA of HCVA and LCVA under photopic conditions were $0.013 \pm 0.003$ and $0.156 \pm 0.005$, respectively. There was no statistically significant difference in HCVA or LCVA between two groups under photopic conditions.
In mesopic conditions, log MAR VA of HCVA and LCVA for emmetropia group were $0.151 \pm 0.004$ and $0.431 \pm$ 0.006. Log MAR VA of HCVA and LCVA for myopic refractive surgery group were $0.146 \pm 0.003$ and $0.453 \pm 0.006$, respectively. There was no statistically significant difference in HCVA or LCVA between emmetropia and myopic refractive surgery groups under mesopic conditions.

\section{Wavefront higher-order aberrations}

Ocular aberrations of total HOA, third-order aberrations, fourth-order aberrations, coma and spherical aberration for $4 \mathrm{~mm}$ and $6 \mathrm{~mm}$ pupils are shown in Table 3 and Fig. 1.

For a $6 \mathrm{~mm}$ pupil size, in emmetropic eyes with ocular aberrations, the RMS values of total HOA, third-order and fourth-order aberrations were $0.547 \pm 0.045 \mu \mathrm{m}, 0.435 \pm$ $0.045 \mu \mathrm{m}$ and $0.276 \pm 0.012 \mu \mathrm{m}$ respectively, and coma and spherical aberrations were $0.342 \pm 0.042 \mu \mathrm{m}$ and $0.224 \pm$ $0.010 \mu \mathrm{m}$. In myopic refractive surgery eyes, the RMS values of total HOA, third-order and fourth-order aberrations were $0.649 \pm 0.06 \mu \mathrm{m}, 0.406 \pm 0.039 \mu \mathrm{m}$ and $0.443 \pm 0.051 \mu \mathrm{m}$

Table 2. Log MAR visual acuity measured under photopic and mesopic lighting conditions

\begin{tabular}{c|c|c|c|c}
\hline \multirow{2}{*}{} & \multicolumn{2}{|c|}{ Photopic Condition } & \multicolumn{2}{c}{ Mesopic Condition } \\
\cline { 2 - 5 } & HCVA $(100 \%)$ & LCVA $(10 \%)$ & HCVA $(100 \%)$ & LCVA(10\%) \\
\hline Post-operative & $0.013 \pm 0.003^{\mathrm{a}}$ & $0.156 \pm 0.0$ & $0.146 \pm 0.003$ & $0.453 \pm 0.006$ \\
\hline Emmetropia $^{\mathrm{p}}-$ value $^{\mathrm{b}}$ & $0.003 \pm 0.005$ & $0.172 \pm 0.008$ & $0.151 \pm 0.004$ & $0.431 \pm 0.006$ \\
\hline $\mathrm{p}=0.518$ & $\mathrm{p}=0.360$ & $\mathrm{p}=0.683$ & $\mathrm{p}=0.205$ \\
\hline
\end{tabular}

${ }^{a}$ Mean \pm standard deviation; HCVA, high contrast visual acuity (log MAR); LCVA, low contrast visual acuity (log MAR); p-value ${ }^{b}$, by independent t-test.

Table 3. Ocular higher-order aberrations for $4 \mathrm{~mm}$ and $6 \mathrm{~mm}$ natural pupils in the myopic refractive surgery group and emmetropia group

\begin{tabular}{c|c|c|c}
\hline Ocular Aberrations & Post-operative & Emmetropia & $\mathrm{p}$-value ${ }^{\mathrm{b}}$ \\
\hline Total HOA $(4 \mathrm{~mm}, \mathrm{RMS}, \mu \mathrm{m})$ & $0.140 \pm 0.005^{\mathrm{a}}$ & $0.161 \pm 0.007$ & $\mathrm{p}=0.223$ \\
\hline Third-order aberrations $(4 \mathrm{~mm}, \mathrm{RMS}, \mu \mathrm{m})$ & $0.117 \pm 0.004$ & $0.145 \pm 0.007$ & $\mathrm{p}=0.084$ \\
\hline Fourth-order aberrations $(4 \mathrm{~mm}, \mathrm{RMS}, \mu \mathrm{m})$ & $0.074 \pm 0.002$ & $0.063 \pm 0.008$ & $\mathrm{p}=0.195$ \\
\hline Coma aberrations $(4 \mathrm{~mm}, \mu \mathrm{m})$ & $0.091 \pm 0.003$ & $0.108 \pm 0.005$ & $\mathrm{p}=0.274$ \\
\hline Spherical aberration $(4 \mathrm{~mm}, \mu \mathrm{m})$ & $0.034 \pm 0.002$ & $0.038 \pm 0.000$ & $\mathrm{p}=0.697$ \\
\hline Total HOA $(6 \mathrm{~mm}, \mathrm{RMS}, \mu \mathrm{m})$ & $0.649 \pm 0.061^{\mathrm{a}}$ & $0.547 \pm 0.045$ & $\mathrm{p}=0.045$ \\
\hline Third-order aberrations $(6 \mathrm{~mm}, \mathrm{RMS}, \mu \mathrm{m})$ & $0.406 \pm 0.039$ & $0.435 \pm 0.045$ & $\mathrm{p}=0.518$ \\
\hline Fourth-order aberrations $(6 \mathrm{~mm}, \mathrm{RMS}, \mu \mathrm{m})$ & $0.443 \pm 0.051$ & $0.276 \pm 0.012$ & $\mathrm{p}<0.001$ \\
\hline Coma aberrations $(6 \mathrm{~mm}, \mu \mathrm{m})$ & $0.353 \pm 0.043$ & $0.342 \pm 0.042$ & $\mathrm{p}=0.803$ \\
\hline Spherical aberration $(6 \mathrm{~mm}, \mu \mathrm{m})$ & $0.396 \pm 0.051$ & $0.224 \pm 0.010$ & $\mathrm{p}<0.001$ \\
\hline
\end{tabular}

${ }^{a}$ Mean \pm standard deviation; HOA, higher-order aberrations; $p$-value ${ }^{b}$, by independent t-test. 


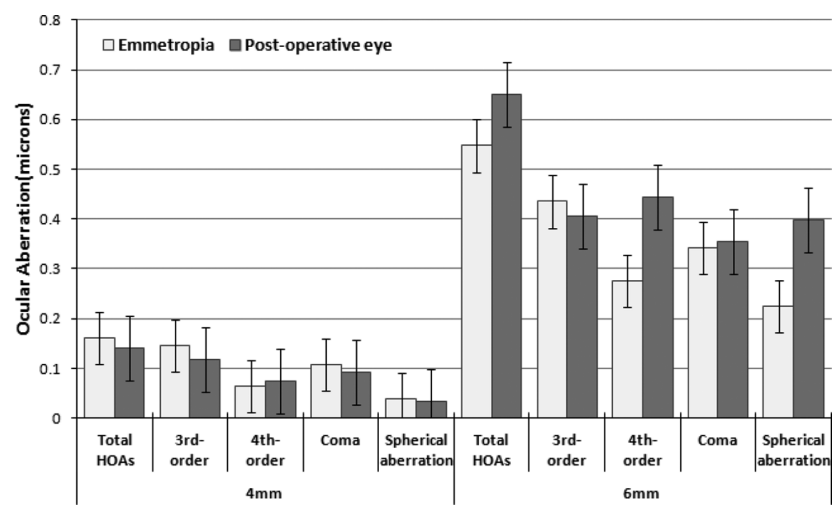

Fig. 1. Comparison of ocular higher-order aberrations (HOAs) for $4 \mathrm{~mm}$ and $6 \mathrm{~mm}$ natural pupils in emmetropia and myopic refractive surgery groups. Total HOA, fourthorder and spherical aberrations for a $6 \mathrm{~mm}$ pupil show significant difference between two groups.

respectively, and coma and spherical aberrations were $0.353 \pm 0.043 \mu \mathrm{m}$ and $0.396 \pm 0.051 \mu \mathrm{m}$. We found that the amount of ocular aberrations in the postoperative eyes for a $6 \mathrm{~mm}$ pupil was generally greater than those in emmetropic eyes. There were significant differences in total HOA, fourth-order and spherical aberrations for a $6 \mathrm{~mm}$ pupil with ocular aberrations between two groups $(\mathrm{p}=0.045$, $p<0.001$ and, $p<0.001$, respectively). However, for a $4 \mathrm{~mm}$ pupil size, the mean values of ocular aberrations in the postoperative eyes were lower than those in emmetropic eyes. There was no significant difference in any ocular aberrations for a $4 \mathrm{~mm}$ pupil between two groups.

Corneal aberrations of total HOA, third-order aberrations, fourth-order aberrations, coma aberration and spherical aberration for $4 \mathrm{~mm}$ and $6 \mathrm{~mm}$ pupils are compared in Fig. 2. For a $6 \mathrm{~mm}$ pupil size, in emmetropic eyes with corneal aberrations, the RMS values of total HOA, thirdorder and fourth-order aberrations were $0.486 \pm 0.024 \mu \mathrm{m}$, $0.351 \pm 0.019 \mu \mathrm{m}$ and $0.309 \pm 0.011 \mu \mathrm{m}$ respectively, and coma and spherical aberrations were $0.273 \pm 0.018 \mu \mathrm{m}$ and $0.269 \pm 0.007 \mu \mathrm{m}$. In myopic refractive surgery eyes, the RMS values of total HOA, third-order and fourth-order aberrations were $0.646 \pm 0.027 \mu \mathrm{m}, 0.373 \pm 0.030 \mu \mathrm{m}$ and $0.492 \pm 0.020 \mu \mathrm{m}$ respectively, and coma and spherical aberrations were $0.339 \pm 0.029 \mu \mathrm{m}$ and $0.467 \pm 0.018 \mu \mathrm{m}$. We also found that there were significant differences in total HOA, fourth-order and spherical aberrations for a 6 $\mathrm{mm}$ with corneal aberrations between two groups $(\mathrm{p}<0.001$, $\mathrm{p}<0.001$ and, $\mathrm{p}<0.001$, respectively). On the other hand, for a $4 \mathrm{~mm}$ pupil, in emmetropic eyes with corneal

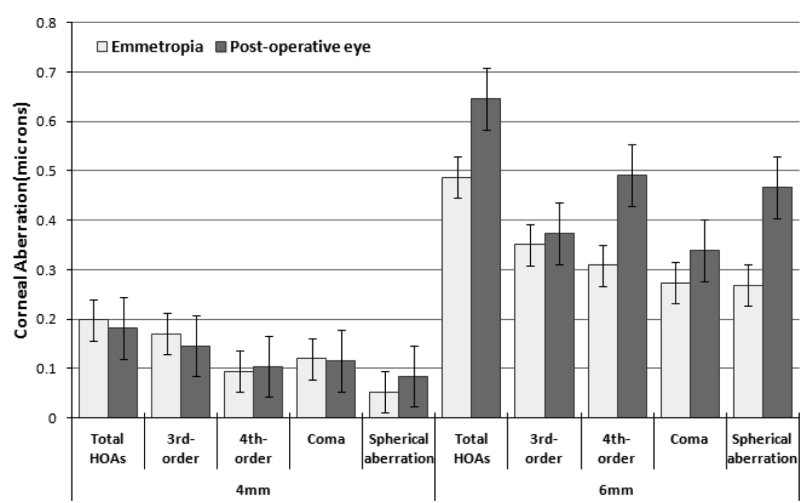

Fig. 2. Comparison of corneal higher-order aberrations (HOAs) for $4 \mathrm{~mm}$ and $6 \mathrm{~mm}$ natural pupils in emmetropia and myopic refractive surgery groups. There were significant differences in total HOA, fourth-order and spherical aberrations for a $6 \mathrm{~mm}$ pupil and spherical aberration for a $4 \mathrm{~mm}$ pupil between two groups.

aberrations, the RMS values of total HOA, third-order and fourth-order aberrations were $0.198 \pm 0.040 \mu \mathrm{m}, 0.170 \pm$ $0.011 \mu \mathrm{m}$ and $0.094 \pm 0.005 \mu \mathrm{m}$ respectively, and coma and spherical aberrations were $0.120 \pm 0.073 \mu \mathrm{m}$ and 0.053 $\pm 0.012 \mu \mathrm{m}$. In myopic refractive surgery eyes, the RMS values of total HOA, third-order and fourth-order aberrations were $0.181 \pm 0.062 \mu \mathrm{m}, 0.146 \pm 0.052 \mathrm{v}$ and $0.104 \pm 0.020$ $\mu \mathrm{m}$ respectively, and coma and spherical aberrations were $0.1156 \pm 0.042 \mu \mathrm{m}$ and $0.084 \pm 0.002 \mu \mathrm{m}$. There was a statistically significant difference in only spherical aberration with corneal aberration for a $4 \mathrm{~mm}$ pupil between the emmetropia and postoperative eyes $(\mathrm{p}=0.001)$.

Comparison of internal aberrations of total HOA, thirdorder aberrations, fourth-order aberrations, coma aberration

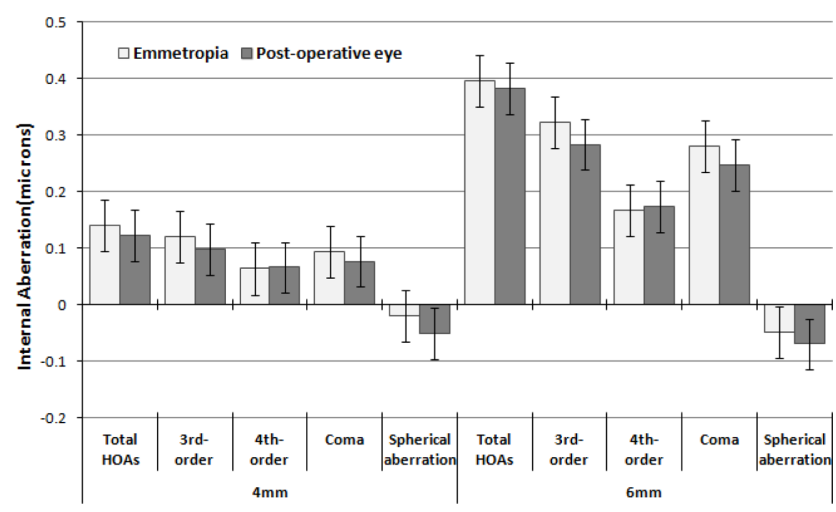

Fig. 3. Comparison of internal higher-order aberrations (HOAs) for $4 \mathrm{~mm}$ and $6 \mathrm{~mm}$ natural pupils in emmetropia and myopic refractive surgery groups. There was significant difference in spherical aberration for a $4 \mathrm{~mm}$ pupil between two groups. 
and spherical aberration in the myopic refractive surgery and emmetropia for $4 \mathrm{~mm}$ and $6 \mathrm{~mm}$ natural pupils is shown in Fig. 3. For a $6 \mathrm{~mm}$ pupil size, in emmetropic eyes with internal aberrations, the RMS values of total HOA, third-order and fourth-order aberrations were 0.396 $\pm 0.034 \mu \mathrm{m}, 0.322 \pm 0.026 \mu \mathrm{m}$ and $0.168 \pm 0.012 \mu \mathrm{m}$ respectively, and coma and spherical aberrations were $0.280 \pm 0.024 \mu \mathrm{m}$ and $-0.049 \pm 0.013 \mu \mathrm{m}$. In myopic refractive surgery eyes, the RMS values of total HOA, third-order and fourth-order aberrations were $0.383 \pm 0.019$ $\mu \mathrm{m}, 0.283 \pm 0.024 \mu \mathrm{m}$ and $0.173 \pm 0.007 \mu \mathrm{m}$ respectively, and coma and spherical aberrations were $0.248 \pm 0.024 \mu \mathrm{m}$ and $-0.070 \pm 0.022 \mu \mathrm{m}$. In emmetropic eyes with internal aberrations for a $4 \mathrm{~mm}$ pupil size, the RMS values of total HOA, third-order and fourth-order aberrations were $0.141 \pm$ $0.010 \mu \mathrm{m}, 0.119 \pm 0.006 \mu \mathrm{m}$ and $0.063 \pm 0.005 \mu \mathrm{m}$ respectively, and coma and spherical aberrations were $0.090 \pm 0.003 \mu \mathrm{m}$ and $-0.020 \pm 0.002 \mu \mathrm{m}$. In myopic refractive surgery eyes, the RMS values of total HOA, third-order and fourth-order aberrations were $0.123 \pm 0.002 \mu \mathrm{m}, 0.097 \pm 0.002 \mu \mathrm{m}$ and $0.066 \pm 0.000 \mu \mathrm{m}$ respectively, and coma and spherical aberrations were $0.076 \pm 0.002 \mu \mathrm{m}$ and $-0.050 \pm 0.000 \mu \mathrm{m}$.
There was only one significant difference in spherical aberrations for a $4 \mathrm{~mm}$ with internal aberrations between two groups $(p<0.001)$.

\section{Corneal asphericity}

The mean values of corneal asphericity(Q) in emmetropia and myopic refractive surgery groups were $0.483 \pm 0.036$ and $-0.254 \pm 0.011$, respectively. The distributions of the Q-values in emmertoia and laser refractive surgery are

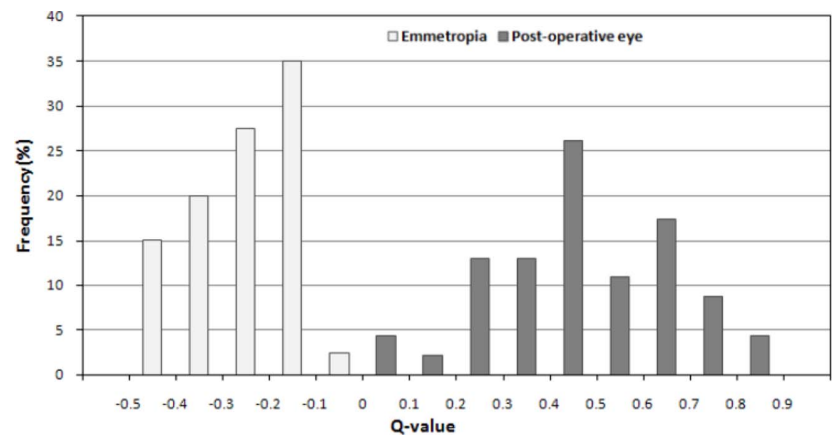

Fig. 4. Distribution of corneal asphericity (Q-value). Zero Qvalue means the cornea is a sphere; negative $Q$-value indicates a prolate cornea; and positive Q-value indicates an oblate cornea.
A
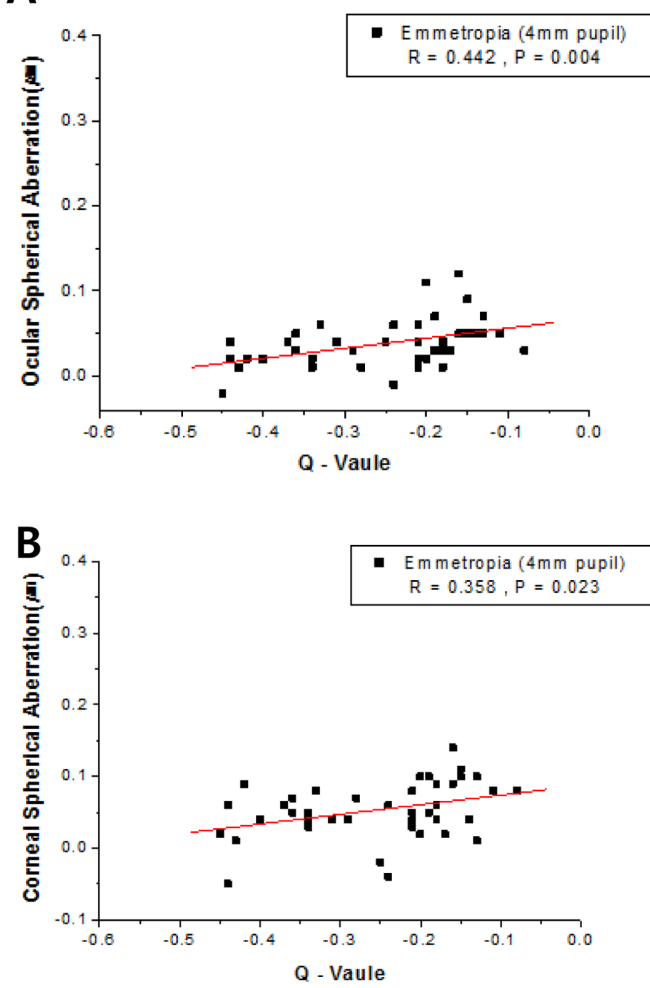
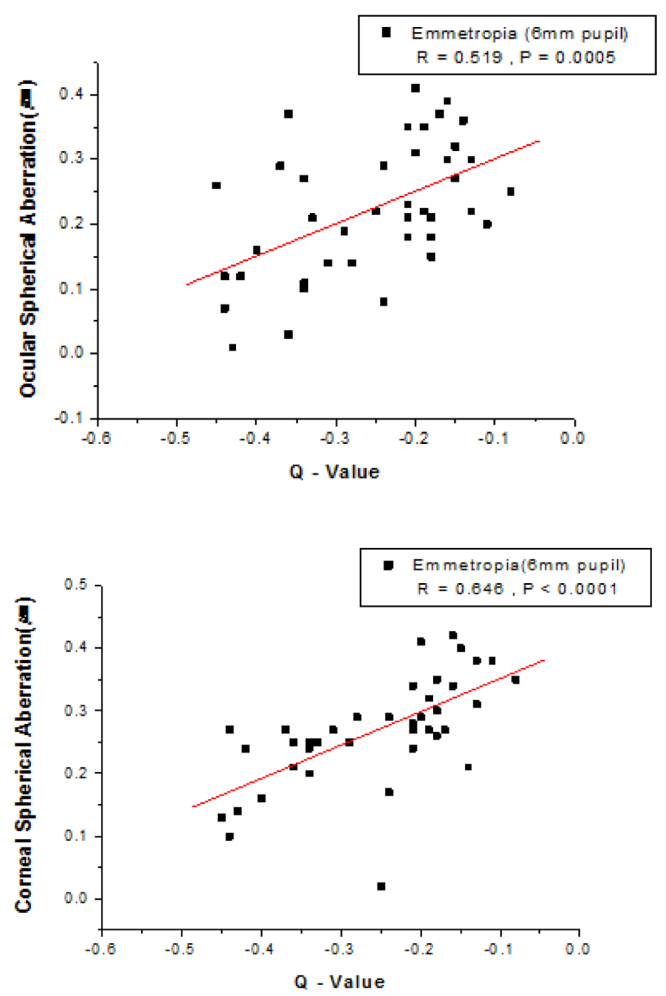

Fig. 5. Effect of corneal asphericity on spherical aberration. (A) The correlation between Q-value and ocular spherical aberration of emmetropia for $4 \mathrm{~mm}$ and $6 \mathrm{~mm}$ pupil sizes, respectively. (B) The correlation between Q-value and corneal spherical aberration of emmetropia for $4 \mathrm{~mm}$ and $6 \mathrm{~mm}$ pupil sizes, respectively. 
illustrated in Fig. 4. Q-value was significantly different between two groups $(p<0.001)$.

The relationship between Q-value and spherical aberration of emmetropia is shown in Fig. 5. In emmetropia with ocular aberrations, a statistically significant correlation was found between Q-value and spherical aberration in ocular aberrations for $4 \mathrm{~mm}$ and $6 \mathrm{~mm}$ pupils $(\mathrm{r}=0.442, \mathrm{p}=0.004$, and $\mathrm{r}=0.519, \mathrm{p}<0.001$, respectively). In emmetropia with corneal aberrations, there was also a significant correlation between Q-value and spherical aberration in corneal aberrations for $4 \mathrm{~mm}$ and $6 \mathrm{~mm}$ pupils $(\mathrm{r}=0.358, \mathrm{p}=0.023$, and $\mathrm{r}=0.646, \mathrm{p}<0.001$, respectively). On the other hand, for post-operative eyes, no significant effects were found between Q-value and spherical aberration in any higherorder aberrations.

There was no significant relationship between the shape of the cornea and the subjects' VA except for one that is significant correlation between Q-value and HCVA (100\%) under photopic condition $(\mathrm{r}=0.519, \mathrm{p}<0.001)$.

\section{DISCUSSION}

After conventional LASIK or LASEK, many myopic eyes experience an increased spherical aberration. ${ }^{[14]}$ Previous studies have reported the importance of HOAs, especially coma or spherical aberration, after refractive surgery, which is associated with halos or glare deteriorated visual quality, ${ }^{[15,16]}$ and the role of HOAs in visual performance have been shown to impact on visual outcomes. ${ }^{[17-19]}$ Our findings agree with previous study that showed the induced spherical aberration plays a significant role for the change in the wavefront error. ${ }^{[20]}$ Increasing of spherical aberration caused an increase in total HOAs with both ocular and corneal aberrations. In fact, ocular HOAs were evaluated rather than corneal HOAs ${ }^{[21]}$ because the ocular HOAs include changes to the posterior cornea and internal pathway of light into the eye even though the refractive effect was performed on the anterior cornea. ${ }^{[22]}$ Our study compared ocular, corneal and internal aberrations between emmetropia and myopic refractive surgery eyes. The finding showed that ocular, corneal and internal HOAs for a 6 $\mathrm{mm}$ pupil were greater in myopic refractive surgery group than those in emmetropia group. The result was that spherical aberration had more strongly effect on the amount of total aberrations than other HOA terms.
Internal optics can be understood as crystalline lens. In internal aberrations, our findings showed that only spherical aberration presents unequally in magnitude to that of the cornea but with opposite sign and the magnitude of other HOA terms was relatively less than those of the ocular or corneal aberrations.

In the present study, the results demonstrated that ocular and corneal HOAs for a $6 \mathrm{~mm}$ pupil were greater than that for a $4 \mathrm{~mm}$ pupil in both emmetropia and myopic refractive surgery groups. This can be explained by the fact that the effect of ocular and corneal aberrations, mainly spherical aberration, on visual quality depends on pupil size,${ }^{[10,11]}$ on which the magnitude of spherical aberration depends.

The corneal surface is prolate when $-1<\mathrm{Q}<0$, oblate when $\mathrm{Q}>0$ and a perfect sphere when $\mathrm{Q}=0$. In our results, the mean of Q-value in emmetropia indicated a slightly prolate cornea (range -0.08 to -0.45 ), whereas, the average cornea in laser refractive surgical eyes presented an oblate cornea (range 0.06 to 0.83 ). In the present study, the result of Q-value in emmetropia was similar to previous study that conducted in adults with early $20 \mathrm{~s}$ to $30 \mathrm{~s} .{ }^{[23,24]}$ This study was analyzed the effect of Q-value from spherical aberration with $4 \mathrm{~mm}$ and $6 \mathrm{~mm}$ pupils. It was found that Q-value is closely related to spherical aberration rather than other aberrations. For the emmetropia with prolate corneal surface, the correlations between Q-value and spherical aberration showed a statistically significant difference in both ocular and corneal spherical aberration for 4 $\mathrm{mm}$ and $6 \mathrm{~mm}$ pupils. It was also found higher correlation between Q-value and spherical with a $6 \mathrm{~mm}$ pupil than between Q-value and spherical aberration with a 4 $\mathrm{mm}$ pupil in both ocular and corneal spherical aberrations. The shape change in the corneal surface through excimer refractive surgery, which alters asphericity of the cornea from a prolate to an oblate shape, could be explained by the induction of spherical aberration ${ }^{[25]}$. However, as confirmed by the results of this study, in laser refractive surgery with change in oblate corneal surface, the correlations did not show a statistically significant difference between Q-value and spherical aberration.

This study did not find a significant relationship between the shape of the cornea and the subjects' VA except for HCVA (100\%) under photopic condition. Emmetropia with prolate cornea and post-operative eyes with oblate cornea 
were equally likely to have best-uncorrected HCVA and LCVA at distance. Changes in corneal asphericity had no influence on HCVA and LCVA both under photopic or mesopic conditions. Previous study reported that retaining preoperative corneal Q-value did not guarantee better VA after refractive surgery for treatment. ${ }^{[14]}$ Given the relationship between VA and ocular HOAs after laser refractive surgery, this study showed that HCVA and LCVA under photopic and mesopic conditions seem not to be influenced directly by ocular HOAs. Therefore, the result that there was no significant difference in VA between emmetropia and laser refractive surgery groups is not surprising, because retinal image quality is the result of combination with various ocular components in optical system, which includes the anterior and posterior corneal surface and crystalline lens. ${ }^{[14]}$ It could be considered the fact that spherical aberration is one of many aberrations in which have an impact on the retinal image quality. Moreover, despite the statistically significant findings of change in spherical aberration, it is still uncertain as to the magnitude of change in HOAs. Although spherical aberration may not affect VA after laser refractive surgery, it may have an influence on the quality of vision with respect to low contrast conditions or low illumination conditions at night. $^{[26]}$

Considering the changes in ocular, corneal and internal aberrations with aging, further studies should be required for the longer-term evaluation between changes in ocular aberrations regarding visual quality after refractive surgery.

\section{CONCLUSIONS}

We found that VA in mopic refractive surgery group is better than or similar to emmetropia group in spite of changes in corneal asphericity. Nevertheless, in both ocular and anterior corneal wavefront aberrations, the more increasing pupil size in the eye is, the more increasing aberrations in that eye are. Thus, increasing spherical aberration after refractive surgery could have an influence on the quality of vision that is related to low contrast sensitivity and low light at night.

\section{REFERENCES}

[1] Porter J, Guirao A, Cox IG, Williams DR. Monochro- matic aberrations of the human eye in a large population. J Opt Soc Am A Opt Image Sci Vis. 2001;18(8):17931803.

[2] Castejón-Mochón JF, López-Gil N, Benito A, Artal P. Ocular wave-front aberration statistics in a normal young population. Vision Res. 2002;42(13):1611-1617.

[3] McLellan JS, Marcos S, Burns SA. Age-related changes in monochromatic wave aberrations of the human eye. Invest Ophthalmol Vis Sci. 2001;42(6):1390-1395.

[4] Liang J, Williams DR. Aberrations and retinal image quality of the normal human eye. J Opt Soc Am A. 1997; 14(11):2873-2883.

[5] Salmon TO, van de Pol C. Normal-eye Zernike coefficients and root-mean-square wavefront errors. J Cataract Refract Surg. 2006;32(12):2064-2074.

[6] Thibos LN, Hong X, Bradley A, Cheng X. Statistical variation of aberration structure and image quality in a normal population of healthy eyes. J Opt Soc Am A Opt Image Sci Vis. 2002;19(12):2329-2348.

[7] Lindskoog Pettersson A, JarkC, Alvin A, Unsbo P, Brautaset R. Spherical aberration in contact lens wear. Contact Lens \& Anterior Eye. 2008;31(4):189-193.

[8] Moreno-Barriuso E, Lloves JM, Marcos S, Navarro R, Llorente L, Barbero S. Ocular aberrations before and after myopic corneal refractive surgery: LASIK-induced changes measured with laser ray tracing. Invest Ophthalmol Vis Sci. 2001;42(6):1396-1403.

[9] Kohnen T, Buhren J. Corneal first-surface aberration analysis of the biomechanical effects of astigmatic keratotomy and a microkeratome cut after penetrating keratoplasty. J Cataract Refract Surg. 2005;31(1):185-189.

[10] Charman WN, Chateau N. The prospects for super-acuity: limits to visual performance after correction of monochromatic ocular aberration. Ophthalmic Physiol Opt. 2003; 23(6):479-493.

[11] Nguyen-Khoa JLD, Gicquel JJ, Lebuisson DAA, Dighiero P, Maille M. Monochromatic ocular aberrations distribution in professional pilots. Invest Ophthalmol Vis Sci. 2005;46(5):E-Abstract 1998.

[12] Gonzalez-Meijome JM, Villa-Collar C, Montes-Mico R, Gomes A. Asphericity of the anterior human cornea with different corneal diameters. J Cataract Refract Surg. 2007; 33(3):465-473.

[13] Yoon JH, Avudainayagam K, Avudainayagam C, Swarbrick HA. Validating a new approach to quantify Posterior corneal curvature in vivo. J Korean Oph Opt Soc. 2012;17(2):223-232.

[14] Tuan KM, Chernyak D. Corneal asphericity and visual function after wavefront-guided LASIK. Optom Vis Sci. 2006;83(8):605-610.

[15] Sharma M, Wachler BS, Chan CC. Higher-order aberrations and relative risk of symptoms after LASIK. J Refract Surg. 2007;23(3):252-256.

[16] Chalita MR, Chavala S, Xu M, Krueger RR. Wavefront 
analysis in post-LASIK eyes and its correlation with visual symptoms, refraction, and topography. Ophthalmology. 2004;111(3):447-453.

[17] Applegate RA, Marsack JD, Ramos R, Sarver EJ. Interaction between aberrations to improve or reduce visual performance. J Cataract Refract Surg. 2003;29(8):1487-1495.

[18] Chen L, Singer B, Guirao A, Porter J, Williams DR. Image metrics for predicting subjective image quality. Optom Vis Sci. 2005;82(5):358-369.

[19] Cheng X, Thibos LN, Bradley A. Estimating visual quality from wavefront aberration measurements. J Refract Surg. 2003;19(5):S579-584.

[20] Buhren J, Nagy L, Yoon G, MacRae S, Kohnen T, Huxlin KR. The effect of the asphericity of myopic laser ablation profiles on the induction of wavefront aberrations. Invest Ophthalmol Vis Sci. 2010;51(5):2805-2812.

[21] Mcalinden C, Moore JE. Comparison of higher order aberrations after LASIK and LASEK for myopia. J Refract Surg. 2010;26(1):45-51.

[22] Marcos S. Aberrations and visual performance following standard laser vision correction. J Refract Surg. 2001; 17(5):S596-S601.

[23] Jeon IC, Jeong WJ, Kang JH. Comparison of corneal asphericity with measuring range. J Korean Oph Opt Soc. 2012;17(4):469-476.

[24] Kim HJ, Lee DH. Corneal asphericity of myopia in Korean. J Korean Oph Opt Soc. 2006;11(2):109-114.

[25] Holladay JT, Janes JA. Topographic changes in corneal asphericity and effective optical zone after laser in situ keratomileusis. J Cataract Refract Surg. 2002;28(6):942947.

[26] Cox I, Holden BA. Soft contact lens-induced longitudinal spherical aberration and its effect on contrast sensitivity. Optom Vis Sci. 1990;67(9):679-683.

\title{
굴절교정수술을 받은 근시안의 각막 비구면도와 광학적 특성 평가
}

\author{
김정미 ${ }^{1}, \quad$ 이아영 ${ }^{1}, \quad$ 이군자 ${ }^{1,2, *}$ \\ ${ }^{1}$ 을지대학교 대학원 안경광학과, 대전 301-832 \\ 2을지대학교 안경광학과, 성남 461-713 \\ 투고일(2013년 4월 30일), 수정일(2013년 5월 23일), 게재확정일(2013년 6월 15일)
}

목적: 엑시머 레이저 근시굴절교정수술을 받은 사람의 각막 비구면도, 시력, 고위수차를 정시안과 비교 평가하였 다. 방법: 단안의 나안 시력이 1.0 이상인 근시 굴절교정수술을 받은 23명(나이: $23.0 \pm 2.5$ 세)과 20 명 $(21.0 \pm 2.6$ 세)의 정시안을 대상으로 밝은 조명(photopic)과 중등도(mesopic) 조명상태에서 대비도를 가지는 시력표 $(100 \%$ 및 $10 \%)$ 를 이용하여 시력검사를 하였고, wavefront 수차 분석기(KR-1W, Topcon, Japan)를 이용하여 각막의 비구면계수와 4 $\mathrm{mm}$ 와 $6 \mathrm{~mm}$ 의 동공크기에 따른 눈 전체의 고위수차와 각막의 고위수차를 측정하여 비교하였다. 결과: 굴절교정 수 술안과 정시안에서 대비도에 따른 시력은 유의한 차이를 보이지 않았다. 안구 수차(ocular aberrations)에서 전체 고 위수차, 4 차수차, 구면수차는 동공크기 $6 \mathrm{~mm}$ 상태에서 굴절교정 수술안에서 높게 나타났고, 두 그룹 사이에 유의한 차이를 보였다 $(\mathrm{p}=0.045, \mathrm{p}<0.001, \mathrm{p}<0.001)$. 각막의 구면 수차(corneal spherical aberrations)는 동공크기 $4 \mathrm{~mm}$ 와 6 $\mathrm{mm}$ 상태에서 모두 굴절교정 수술 안에서 더 높게 측정되었고 유의한 차이를 보였다 $(\mathrm{p}<0.01, \mathrm{p}<0.001)$. 각막의 전체 고위수차와 4차수차는 동공크기 $6 \mathrm{~mm}$ 상태에서만 굴절교정 수술안에서 더 크게 나타났고 통계적으로 유의하였다 $(\mathrm{p}<0.001, \mathrm{p}<0.001)$. 정시안의 비구면계수와 구면수차는 동공크기 $4 \mathrm{~mm}$ 와 $6 \mathrm{~mm}$ 상태에서 안구 수차 $(\mathrm{r}=0.442$, $\mathrm{p}=0.004, \mathrm{r}=0.519, \mathrm{p}<0.001)$ 와 각막수차 $(\mathrm{r}=0.358, \mathrm{p}=0.023, \mathrm{r}=0.646, \mathrm{p}<0.001)$ 모두에서 유의한 상관성을 나타내었으 나, 굴절교정 수술안에서는 상관성이 없었다. 결론: 각막굴절교정 수술안의 경우 시력은 정상수준을 나타내고 있으 나 동공크기가 커지면 수차가 증가하여 동공이 커지는 야간에는 시력의 질에 영향을 줄 수 있을 것으로 사료된다.

주제어: 고위수차, 구면수차, 각막 비구면계수, 굴절수술 